\title{
Dynamics of the adventive component in the flora of Barnaul
}

\author{
Marina Silanteva ${ }^{*}$, and Tatyana Terekhina \\ Altai State University, Botany Department, 61 Lenin Str., Barnaul, 656049, Russia
}

\begin{abstract}
The article considers the results of the floristic study as well as the analysis of the archival records and literature data in order to reveal the dynamics and the specific features of the adventive element formation in the flora of Barnaul throughout its history. It provides data on the time of some species introduction into the city area.
\end{abstract}

\section{Introduction}

It is necessary to turn to the history of the Barnaul city in order to understand the specific aspects of the adventive element formation on its territory. Barnaul was founded (according to one theory) in 1730 by the Ural manufacturer A. Demidov. The construction of the Barnaul silver-smelting plant in 1739-1744 was one of the steps in the industrial mining development of the Altai territory, which did not have cities and large settlements as well as developed agricultural production before that. Intensive colonization of the Altai territory by the Russian people began only in the 1720 s. It was closely associated with the discovery of rich copper and silver ore deposits in the northwestern foothills (the city of Zmeinogorsk and its outskirts). It was in 1749, when the executive office of the entire newly created mountain district was transferred to Barnaul and the city began to develop as an industrial and administrative center. A technical library comprising 7 thousand volumes was opened in 1764. In 1771, Barnaul gained the status of a mountain city where the first school of mines in Siberia was established. Archival records from 1786 mention the Barnaul "theater house".

Initially, the area of the city was limited by the Ob River in the east and southeast, and by the winding forest in the southwest and west, so that the city grew northwards. The city was developing in the Barnaulka River valley, close to its mouth (the confluence of the Barnaulka and the Ob Rivers), claiming flood meadows, dry meadows of terraces and birch as well as pine forests. In terms of natural conditions, the territory of the city is the right bank forest-steppe.

\section{Results}

In 1779, a corresponding member of the St. Petersburg Academy of Sciences E. Patren compiled the first inventory of plants in the vicinity of Barnaul "Flora barnaulensis". This

\footnotetext{
*Corresponding author: msilan@mail.ru
} 
catalog specifies 244 plant species [1]. The publications of the XVIII century preserved the information on what the inhabitants of the city cultivated. Thus, in 1796, I. Sivers, a corresponding member of the St. Petersburg Academy of Sciences, provided the data on the cultivation of strawberries, cucumbers, melons and watermelons in Barnaul in "Letters from Barnaul" published in the "Works of the Free Economic Society".

The introduction of adventive species was also due to the pharmacy gardens. In 1800, S. Shangin set out a small botanical garden with a greenhouse for thermophytes in the place of the pharmacy garden at the Barnaul Central Hospital. Up to 400 species of plants were grown in the botanical garden; there was a plantation of rhubarb [2,3].

At the beginning of the XIX century, the city became a major cultural, scientific and engineering center of Russia. In 1827, the first printing office and the museum of regional studies, one of the first in Siberia, were established. Apparently, the arriving Cossacks and mountain officers, graduates of St. Petersburg Mining Institute, brought various planting material from different places of Russia. In the published list of the Altai Mountains plants, probably determined by Fisher himself [1], I. Brykov [4], a future famous doctor and writer, indicated, along with the cultivated Convallaria majalis, Borago officinalis, Coryllus avellana, Aquilegia vulgaris, etc., a number of weed adventive species introduced together with the cultivated ones: Agrostemma githago, Echium vulgare, Betonica officinalis, Malva crispa, Raphanus raphanistrum, Lamium purpureum, Lepidium ruderale, Brassica campestris, Sinapis arvensis, Sonchus oleraceus, Fumaria officinalis, Centaurea cyanus, C. jacea, Matricaria chamomilla, Anthemis tictoria, Asperugo procumbens, and others.

In 1835, more than 9 thousand people lived in Barnaul. In 1864, S. I. Gulyaev published a note on the development of gardening and horticulture in Barnaul. Mentioning that vegetable gardening serves merely the needs of the townspeople themselves, he reported that they sold cucumbers, melons, watermelons, potatoes and cabbage. The list of vegetable crops grown by the people in Barnaul was significant. It was specified that "gardening in its direct meaning did not exist in Barnaul", "and private gardens looked like small gardens in St. Petersburg on the Vyborg side, in Koltovskaya, Kolomna and Gavan". In gardens and vegetable gardens, one could see the birch, bird cherry, linden (from the Kuznetsk district), pine, cedar, mountain ash, buckthorn, guilder rose, honeysuckle, meadowsweet, shadbush, coloneaster, Kalmyk peaches (almonds), sea buckthorn, and hawthorn. One cannot but mention raspberries, currants, gooseberries among berry-producing shrubs and the Siberian apple tree among fruit trees [5]. At the same time, a future famous botanist A. N. Krasnov specified Malva borealis, Lycopsis arvensis, Elsholtia ciliata, Urtica cannabina as adventive weeds introduced to Barnaul by people [6].

By the 1870s, the city's population reached 13-14 thousand people. The decline of the mining industry and the shutdown of the Barnaul plant in 1893 led to a shift in the role of the city. It became a major trading center of a developing agricultural region.

In 1885-1890, the oldest amateur gardens of Barnaul were set out. Both seedlings of European fruit trees varieties and forms of Siberian apple trees were grown there. Widescale planting of gardens in the region began in 1894-1902, when the district headquarters began to lease land plots in the outskirts of the city for long-term periods of 24 years [7]. A lot of dachas (summerhouses) and zayimkas (small isolated settlements on uncultivated land or hunters' cabins) appeared in the suburbs of Barnaul. Gardeners of that time introduced such species as pedunculate (common) oak, European white elm, balsam poplar, Tartarian and Norway maple, small-leaved and Siberian linden, Siberian apple and its hybrids, shadbush, sloe, common lilac, mock orange and many others [8].

After the Civil war of 1917-1919 and the catastrophic fire of 1917, the city in fact, turned into the center of the region's agro-industrial complex, and vegetable gardens became an integral part of the city landscape. 
In 1930, V. I. Vereschagin became the second researcher in the history of Barnaul to create its flora. However generally, we accept his list as the first "Flora of Barnaul", since Patren's list, preserved in the archives, was not in common scientific use. "The List of Plants in the Vicinity of Barnaul" by V. I. Vereschagin [9] was compiled on the basis of the materials collected on the left bank of the Ob in 1900-1929 and on the right bank in the flood meadows along the Talaya and the Losikha Rivers. The list contains 743 species.

In the post-war period, gardening quickly developed in Altai. The process became especially intense since the 1960s. M. A. Lisavenko Siberian Research Institute of Horticulture (SRIofH) made a particularly outstanding contribution to the enrichment of the city's flora with decorative trees and shrubs. The basis of the woody plants assortment was presented by 33 species of trees and more than 60 species of shrubs [7]. A number of introduced species (European white elm, common oak, Pallas apple tree, small-leaved linden, green ash, maple ash, etc.) were able to regenerate naturally even in the conditions of the forest-steppe and now constitute an adventive element of the city's flora.

In the $80-90$ s of the last century, there was a steady rise in private landholding (gardens and summerhouses, estates). The interest of the population in landscaping with the use of phytodesign techniques and the use of exotic planting and seed material increased. Spontaneous introduction is currently significant. In the vicinity of the city and in its streets, one can see Thladiantha dubia, cultivars of Aquilegia vulgaris, Ipomea purpurea, Xanthoxalis stricta, etc. at landfill sites.

Currently, the population of the city is about 700,000 people. In the city area, the vegetation cover is represented mainly by artificial plantations - alleys, public gardens, boulevards, lawns and parks. The outermost northeastern part of the Barnaul pine forest formed by the common pine is situated in the upland part of the city along the Barnaulka River on the sandy ridges. The area of Nauchnyi Gorodok is characterized by aspen-birch outliers and steppe plots. The city is surrounded by horticultural and agricultural lands.

The study of the city flora in the 1990s by the Botany Department team allowed identifying only 578 species of higher vascular plants within the precincts of the city. In our opinion, such an outcome is the result of dense urban development, a decrease in the share of natural phytocenoses and an increase in the share of anthropogenically transformed ones, unification of landscaping, and a reduction in the number of private residences. Native species of natural habitats that cannot tolerate an increase in anthropogenic load keep falling out. Alien species and escapees from cultivation amounting to 90 species (14.5\%) dominated among the newly introduced plants. All these changes indicate an increase in the degree of the flora anthropogenic transformation. By the beginning of the 21 st century, 200 adventive plants belonging to 48 families and 143 genera were identified (34.3\% of all flora species).

In the $30 \mathrm{~s}-50 \mathrm{~s}$ of the XX century, 55 adventive plant species of 46 genera and 17 families grew in the city. Most of the families were represented by 1-3 species (Cuscutaceae, Fumariaceae, Violaceae, Fumariaceae, Rubiaceae, Amaranthaceae, Polygonaceae, Malvaceae, Fabaceae, Boraginaceae, Lamiaceae, Solanaceae). From 4 to 14 species belonged to the families of Chenopodiaceae, Caryophyllaceae, Poaceae, Asteraceae, Brassicaceae.

In the 1990s, new adventive plants of the Ulmaceae, Cannabaceae, Aceraceae, Balsaminaceae, Elaeagnaceae, Onagraceae, Apiaceae, Cucurbitaceae, Gentianaceae, Papaveraceae families appeared. They were represented by one species each. Previously identified adventive species also retained their representation in general. In total, the representatives of 28 families and 68 genera of adventive plants grew on the territory of the city during this period [10].

By the beginning of the XXI century, there was a sharp rise in the number of adventive species in the city's flora. New species representing the families (1 species per a family) of 
Commelinaceae, Salicaceae, Plumbaginaceae, Urticaceae, Portulacaceae, Fagaceae, Juglandaceae, Vitaceae, Tiliaceae, Hydrangeaceae, Rutaceae, Scrophulariaceae, Plantaginaceae, Oleacae, Campanulaceae, Euphorbiaceae, Ranunculaceae, Grossulariaceae, Rosaceae were identified. A part of the adventive plant species transformed into the category of invasive ones and significantly increased their abundance. Thus, Hordeum jubatum L. has been found in Barnaul since 1977 and has become a common species on lawns and wastelands. At the end of the last century, Echinocystis lobata (Michx.) Torr. et Gray was encountered accidentally in shady ravines, along river banks, at landfill sites near the Gonba village. Currently it is common along the $\mathrm{Ob}$ floodplain near horticultural communities. Over a hundred-year period of use, it has become a common sight in the city, propagating by seeds. Portulaca oleracea L. was rarely found in vegetable gardens, on the lawns, flowerbeds, and along the roadsides. Currently, in 10 years' time, it has sharply increased its abundance, forming a continuous cover along the roads throughout the city. Birds actively spread Amelanchier spicata (Lam.) C. Koch from old gardens. Acer negundo L. forms undergrowth all over the forest, as well as in the city parks and in horticultural communities on uncultivated plots. Birds contributed to its active settlement. Pastinaca sylvestris Mill. is an ordinary weed in vegetable gardens, and it forms continuous thickets along the roads. Recently, Cyclachaena xanthifolia (Nutt.) Fresen has been identified in Barnaul. In the south of the region, it occupied wastelands and roadsides; in Barnaul, it is very active in all synanthropic habitats, forming thickets. Solidago canadensis L. has long been grown in gardens and escapes cultivation occupying abandoned plots and roadsides.

\section{Conclusion}

The formation of the adventive species complex in the flora of Barnaul has its own specificity. It is determined by the types of nature management, transformed in different historical periods and leading to the creation of new habitats: ore processing; creation of hydraulic systems (dams, ponds); deforestation and afforestation; gardening, horticulture, floriculture; formation of a transport network; expansion of the built-up area and recreational territories. These new habitats have become a springboard for the introduction of a number of species. About 15 species of the identified 200 adventive plants species in Barnaul have become invasive in recent years.

\section{References}

1. I. Borodin, Collectors and collections of the Siberian flora (St. Petersburg, 1908)

2. G. I. Kurnykina, I. P. Shangin, Daily notes to the executive office of KolyvanoVoskresenskiy mountain authorities on the trip to Kirgiz-Kaysatskaya steppe (Barnaul, Az Buka, 2003)

3. N. A. Kambalov, Alt., 4 (39), 98 (1966)

4. I. Brykov, Uk. otkr. po fiz., khim., yest. ist. i tekhnol., izd. N. Scheglovym, 7/1, (1830)

5. S. Gulyaev, VROS in StPbg, 1, 15 (1864)

6. A. N. Krasnov, Botan. zap., 1, 181 (St. Petersburg, 1886).

7. Z. I. Luchnik, Byull. GBS, 142, 12 (1986)

8. Z. I. Luchnik, Introduction of trees and shrubs in Altai Region (1970)

9. V. I. Vereschagin, The list of plants in the vicinity of Barnaul. Alt. collection, 12 (1930)

10. T. A. Terekhina, Anthropogenic phytosystems (2000) 